Pamiętnik Literacki 2016, 1, s. 27-41

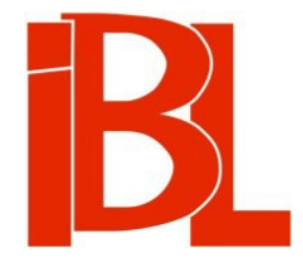

\title{
Miasto śmierci. Epizod z włoskiej kampanii \\ Kraszewskiego
}

Piotr Chlebowski 
PIOTR CHLEBOWSKI Katolicki Uniwersytet Lubelski Jana Pawła II

\section{MIASTO ŚMIERCI EPIZOD Z WŁOSKIEJ KAMPANII KRASZEWSKIEGO}

Józef Ignacy Kraszewski miał - jak przystało na pisarza XIX stulecia - swoja grand tour $^{1}$. Odbył ją w 1858 roku; trasa prowadziła przez Polskę, Italię, Francję, Belgię i Niemcy. A gdy w 1866 i 1874 roku relacja z tej podróży ukazała się w postaci dwu ksiag zatytułowanych Kartki $z$ podróży. 1858-1864, z łatwością można było się zorientować, że włoski odcinek należał do najważniejszych i najdłuższych jej elementów. Oczywiście, europejska eskapada $z$ roku 1858 nie była pierwszą wyprawą Kraszewskiego-wędrowca: pisarz przecież od najmłodszych lat przemierzał ogromne obszary ziem ruskich i litewskich, dawne ziemie Rzeczypospolitej, co skutkowało powstawaniem rozmaitych obrazów i motywów pejzażowych, sytuacyjnych i historycznych, skutecznie zapełniających jego teksty literackie, ale także publicystyczne. Utrwalał własne wrażenia również w postaci rysunków i akwarel. Zgodnie też z ówczesnym zwyczajem ogłaszał swoje podróżnicze relacje. W roku 1840 - zwróćmy uwage - wydał Wspomnienia Wotynia, Polesia i Litwy ${ }^{2}$ - z tzw. fizjologiami wielkich miast tego obszaru3 ${ }^{3}$. W 2 lata później ukazały się Obrazy z życia i podróż $y^{4}$ : zapis wrażeń i spostrzeżeń $z$ wyprawy, jaką odbył Kraszewski przemierzając szlak od Lublina do Wilna. Po podjętej zaś latem 1843 tzw. wyprawie wschodniej utrwalił on zarówno w postaci zapisków, jak i szkiców rysunkowych swoje doświadczenia i refleksje we Wspomnieniach Odessy, Jedyssanu i Budżaku

1 Zob. „Do ziemi naszej” - podróże romantyków. Wybór J. Ka mi o n k a - S tra s z a k o w a. Warszawa 1988. - S. B u rk ot, Polskie podróżopisarstwo romantyczne. Warszawa 1988. - J. Ka m i o nk a - Str a s z a k ow a, Podróż. Hasło w: Słownik literatury polskiej XIX wieku. Red. J. B a c h ó r z, A. Kowalczykowa. Wrocław 1991.

2 J. I. Kraszew s ki, Wspomnienia Wotynia, Polesia i Litwy. T. 1-2. Wilno 1840.

3 W tamtym okresie J. I. Kra s z ew s ki publikował też szkice o charakterze podróżniczym w czasopismach: Prużana. „Tygodnik Petersburski” 1837, nr 79; Bekieszówka pod Wilnem. „Biruta” 1838; Podróż po szybach karczemnych. „Tygodnik Petersburski” 1838, nr 38; Międzyrzecz Korecki i Raśniki. „Dziennik Domowy” 1840, nr 21; Kodeń nad Bugiem. „Athenaeum” (Wilno) 1841, t. 4; Domy i ludzie. (Wędrówka). „Kalendarz Wolnego Miasta Krakowa” 1844; Tajemnice wód. „Ondyna Druskienickich Źródeł” 1845, z. 5. S. Burkot (Podróże Józefa Ignacego Kraszewskiego. W: Kraszewski. Szkice historycznoliterackie. Warszawa 1988, s. 123-124) zwraca uwagę, że podróże krajowe Kraszewskiego wpisywały się w utrwaloną po upadku niepodległości tradycję odnotowywania pamiątek narodowych, zabytków, muzealiów, zasobów bibliotecznych, obyczajów jako rodzaj inwentaryzacji tego, co ocalało po wojennych zniszczeniach i grabieżach.

4 J. I. Kras zew s ki, Obrazy z życia i podróży. T. 1-2. Wilno 1842.

5 J. I. Kraszew ski, Wspomnienia Odessy, Jedyssanu i Budżaku. Dziennik przejażdżki w roku 1843, od 22 czerwca do 11 września. T. 1-3. Wilno 1845-1846. 
Na tym tle obraz wyprawy europejskiej rysuje się ciekawie już choćby $\mathrm{z}$ tej prostej przyczyny, że zupełnie traci status „przejazdki po własnym kraju”6. Fakt, iż podróż 1858 roku stanowiła pierwsze bezpośrednie zetknięcie się Kraszewskiego z kulturą i cywilizacją południowej i zachodniej Europy, miał też ogromny wpływ na przyjęte cele wyprawy. Wiązały się one z potrzeba obserwacji zmian, jakie zachodziły na kontynencie po wojnach napoleońskich, wypadkach roku 1830, Wiośnie Ludów i, oczywiście zakończonej wojnie krymskiej. Europa przechodząca ogromne przeobrażenia kulturowe we wszystkich dziedzinach: od polityki po modę, pozostawiająca „wiek kupiecki” i podażająca ku nowemu „wiekowi przemysłowemu” ${ }^{7} \mathrm{mu}$ siała być jednym $z$ głównych przedmiotów obserwacji. Ale też w tamtym okresie nie tylko twórca Starej baśni starał się odczytywać współczesność poprzez historię i pomniki czasu minionego. Wyłącznie konfrontowanie tego, co dawne, z tym, co aktualne, dawało możliwość zbliżenia poznawczego i zrozumienia chwili obecnej, także sytuacji Polski. Pod tym względem Kraszewski był wiernym „dziecięciem swego wieku". Zestawianie i porównywanie miało również swoje podstawy w założeniu bardziej praktycznym i chyba oczywistym, zwłaszcza w przypadku „włoskiej kampanii”. Chodziło o dopełnienie studiów $z$ historii sztuki, niezbędnych dla przygotowywanej właśnie do druku Ikonotheki, będącej ex definitione rodzajem encyklopedii sztuki i słownika polskich artystów. Stąd też problematyka ta wysunęła się na pierwszy plan wśród podróżniczych celów pisarza - miała stanowić zasadniczy i najszerzej potraktowany temat wyprawy. Oto słowa Kraszewskiego:

Jednym $\mathrm{z}$ celów mojej podróży było dopełnienie po kilkakroć w ciągu życia przedsiębranych i rzucanych studiów tyczących się dziejów sztuki w ogóle, a szczególniej stosunku ich do historii sztuki krajowej. Zwróciłem się więc tam naprzód, gdzie widzeniem dawnych zabytków mogłem się nasycić i nauczyć. [K-1 105] ${ }^{8}$

Jednym $\mathrm{z}$ najistotniejszych punktów grand tour w tym dopełnianiu studiów „Z dziejów sztuki” były Pompeje - z uwagi na znaczenie owego miejsca dla kultury i literatury XIX wieku ${ }^{9}$ oraz na fakt, że wciąż było ono niemała sensacją archeologiczną; wprawdzie pierwsze zorganizowane prace prowadzono tu od 100 lat, ale

6 J. I. Kr a s z e w s k i, Wspomnienia Odessy, Jedysanu i Budżaku. Dziennik przejażdżki w roku 1843, od 22 czerwca do 11 września. Oprac. P. Hertz. Warszawa 1985, s. 9.

7 „Wiek kupiecki”, „wiek przemysłowy” - to określenia użyte przez Z. S t e fa n o w s ką (Pisarz wieku kupieckiego i przemysłowego. W: Strona romantyków. Studia o Norwidzie. Lublin 1993) do opisania sytuacji przełomu kulturowego, dokonującego się w Europie w okresie, gdy tworzył C. Norwid.

8 Skrótem K odsyłam do: J. I. Kr a s z e w s k i, Kartki z podróży. 1858-1864. T. 1-2. Przypisy, posł. P. He rtz. Warszawa 1977. Pierwsza liczba po skrócie, po łączniku, oznacza numer tomu, następne - stronice.

9 Trzeba tu przynajmniej wymienić istotną dla romantyków i zarazem słynna powieść E. Bulwera-Lyt to na The Last Days of Pompeii. Jej pierwsze wydanie ukazało się w Londynie w 1834 roku. Rzecz doczekała się w tamtym czasie licznych wznowień i przekładów. O skali popularności dzieła Lyttona niech zaświadcza fakt, że właśnie wtedy, gdy Kraszewski odbywał swoją podróż, czyli w r. 1858, E. Petrella skomponował operę Jone, do której libretto napisał, na podstawie Ostatnich dni Pompejów, G. Peruzzini. Miała ona swoją premierę w mediolańskiej La Scali 26 I 1858, do końca XIX w. była stałym punktem programu wielu europejskich teatrów operowych. W połowie XIX w. francuski artysta A. Guesdon odbył podróż balonem nad ruinami Pompejów, co potem zaowocowało ogromną liczbą sztychów przedstawiających panoramiczne widoki miasta oraz 
w tamtym okresie udawało się archeologom wciąż odkrywać nowe budowle i nowe dzieła sztuki ${ }^{10}$. Było to miejsce obowiązkowych podróży krajoznawczych i wypraw romantycznych, eksplorujących oblicza upadku cywilizacji, przemijania i kruchości dorobku ludzkiego ${ }^{11}$. Kraszewski nie kryje w zapiskach, że na szlaku jego podróży to właśnie Pompeje i Herkulanum, obok zabytków pierwszych wieków chrześcijaństwa (zwłaszcza rzymskich katakumb), stanowiły centralny punkt programu:

przynajmniej dla mnie wycieczka ta stanowiła najważniejszy cel podróży przedsięwziętej niemal wyłącznie dla katakumb rzymskich i wykopalisk pompejańskich. Pierwszych wieków chrześcijaństwa ani świata starożytnego pojąć, nie widząc, nie zbadawszy nieco tych zabytków, niepodobna. Pobyt w Neapolu miał też na celu przygotować nas zwiedzaniem muzeów do lepszego zrozumienia szczątków miast zasypanych. [K-2 153]

Zanim Kraszewski przystąpi do zasadniczej relacji, obuduje ją skutecznie całym zespołem informacji wstępnych - jak powiada - „o mieście zasypanym i kraju tym w starożytności" [K-2 153]: o warunkach geograficznych Kampanii, o roli i znaczeniu osady pompejańskiej, o historii wpływów greckich, rzymskich i kartagińskich; o wieku złotym: o rozkwicie i rozwoju miasta, o jego straszliwej tragedii z 79 roku. Dalej: o nieudanych próbach odbudowy Pompejów i kolejnej erupcji Wezuwiusza z 472 roku po Chr., przypieczętowującej ostatecznie tragiczny los miasta oraz jego mieszkańców; i wreszcie o zawiłej, bogatej historii wykopalisk, które na dobre ruszyły ponad 100 lat wcześniej $^{12}$. Ten ciąg informacyjny jest nacechowany rzeczowym i niemal reportażowym stylem - Kraszewski nie kryje swojej wiedzy oraz erudycji,

umożliwiło pełne rozpoznanie jego urbanistycznych założeń (zob. J. H a r r i s, Pompeii Awakened. A Story of Rediscovery. New York 2007, s. 175).

10 W latach 1815-1860 odkopano chyba największą liczbę ważnych publicznych budynków oraz ulic miasta, np.: bazylikę (1813-1819), świątynię Apollina (1816-1820), Forum (1820), świątynię Fortuny Augusty (1824), Dom Poety Tragicznego (1824), Dom Pansy (właśc. Dom Arriana, 1827), Dom Centaura (1829-1830), Dom Fauna (1830-1832), Dom z Labiryntem (1834), świątynię Apollina (1835), świątynię Orfeusza (1843-1849), mury przy Bramie Morskiej (1850) oraz Termy Stabiańskie (1854-1859). W przypadku tej ostatniej budowli prace wykopaliskowe w trakcie wizyty Kraszewskiego były w pełnym toku.

11 Te wędrówki były już dość popularne w w. XVIII - zob. np. T. Mikocki, Pompeje $w$ relacjach podróżników polskich $w$ XVIII $w$. „Acta Universitatis Wratislaviensis. Antiquitas” t. 11 (1984): Acta Pompeiana. Księga pamiatkowa Ogólnopolskiego Sympozjum w Karpaczu: Pompeje - 1900-lecie wybuchu Wezuwiusza (79-1979).

12 Pierwsze wykopaliska na tym terenie przeprowadzono w 1689 r. przy okazji... pogłębiania studni. Później za sprawą władców i magnatów zaczęto organizować wyprawy i powoli, krok po kroku, wydobywać na powierzchnię przedmioty i całe miasto. W latach 1738-1745 nadał większy rozmach tym przedsięwzięciom archeologicznym i przygotowywał dla nich plan władca Hiszpanii, Karol III (dotyczyły one wówczas zarówno Pompejów, jak i Herkulanum). Zainicjowane przez niego prace, dzięki pomocy inżyniera R. J. de Alcubierre'a, miały charakter systemowy i bardzo przemyślany. Początkowo koncentrowały się głównie na Herkulanum; w r. 1748 przeniesiono je do Pompejów: tę datę powszechnie przyjmuje się za datę zainaugurowania oficjalnych wykopalisk na tym terenie. Szczegółową relację o tym znajdujemy u R. É ti e n n e'a w książce Życie codzienne w Pompejach (Przeł. T. Kotula. Warszawa 1971, s. 38-61). Na temat pierwszych odkryć Pompejów zob. L. H a u t e c œ u r, Rome et la renaissance de l'antiquité à la fin du XVIIIe siècle. Paris 1912, s. 79 n. - E. C. Corti, Vie, mort et résurrection d'Herculanum et Pompéi. Paris 1953. - A. Ma iu ri, Pompei ed Ercolano. Fra case e abitanti. Wyd. 2. Milano 1959. - P. Zan k er, Pompeii: Public and Private Life. Cambridge, Mass., 1998. - A. E. C o o le y, Pompeii. London 2003. - R. Li n g, Pompeii: 
której źródło stanowią, oczywiście, fachowe publikacje, ale także beletrystyczne i popularne, jak np. ówczesne przewodniki. Informacje te odgrywają rolę elementów poprzedzających i wstępnych zasadniczej relacji z wojaży - podawane są zresztą (co znamienne dla podróżopisarskiej konwencji) w trakcie drogi z Neapolu do Pompejów. Stanowia zatem rodzaj tła akustycznego - pudeł rezonansowych ${ }^{13}$, pozwalajacych wybrzmieć głównemu sprawozdaniu w sposób pełniejszy i głośniejszy.

Przestrzenie zwykłych miast - przedstawianych w Kartkach $z$ podróży - wciąż na nowo aktualizujące historię i uobecniające każdą chwilę oraz wartości ludzkich działań z przeszłości, mają ów niezwykły życiodajny puls, który pozwala patrzeć na to, co dawne i minione, jak na współczesne, a $z$ kolei współczesne wpisywać w ciąg zanurzony w wartki strumień procesu przemian. Z Pompejami musiało być inaczej - to przecież miasto z zamkniętą historią, tragedią śmierci i upadku zarazem, katastrofy wkomponowanej nie tylko w dzieje, ale wręcz w krajobraz i w architekturę, a raczej w to, co $\mathrm{z}$ owej tragedii pozostało lub co udało się wydrzeć ziemi i popiołom wulkanicznym. Charakterystyczny dla Kraszewskiego-podróżnika typ epistemologicznego zachowania, cechujacy się zachłannością i bezkompromisowością, ustępuje miejsca gestom wyboru i świadomie głębokiej refleksji. Artysta nie dąży zatem do starannego i systematycznego opisu wszystkiego, co można było w Pompejach zobaczyć, ale zdaje relacje $z$ tego, co przyciąga jego uwagę:

Niech łaskawy czytelnik jednak nie wymaga po nas, abyśmy mu szczegółową sprawę zdali z widoku miasta, z jego gmachów i osobliwości, których opis starczyłby na księgi całe - wyspowiadamy mu się z wrażeń naszych i co ciekawsze opowiemy, wyczerpać tych skarbów niepodobna. [K-2 163]

Wybór i selekcja opisywanych obiektów w Pompejach, mimo przyjętej formy niemal reportażowej, zakładającej silny element obiektywizacji, prowadzi nas ku sensom naddanym, ku znaczeniom wykraczającym poza relację $z$ wizyty w określonym miejscu. Znamienne przy tym, że Kraszewski przekraczając mury miejskie staje się mało precyzyjny i konkretny w zakresie topografii. O ile podróż ku miastu obfituje w geograficzno-historyczne szczegóły ${ }^{14}$, czasem wręcz obciążone balastem

History, Life and Afterlife. Stroud 2005. - J. B e r ry, The Complete Pompeii. New York 2007. - The World of Pompeii. Ed. J. J. D o b b in s, P. W. F o s s. New York 2007. ski, T. Makowie cki, I. Sławińs ka, O Norwidzie pięć studiów. Toruń 1949, s. 9 n.). i znaczeniu osady pompejańskiej, a później - na miastach w regionie, na historii wpływów greckich, rzymskich i kartagińskich. Przez długi okres Pompeje opierały się rzymskiej dominacji, były niszczone i palone w trakcie wojen (np. przez Sullę w I w. przed Chr.), później nastapił ich gwałtowny rozwój, w znacznym stopniu związany z osiedlaniem się (najczęściej czasowym) na tych terenach bogatych Rzymian: „Wybrzeża okryły się tymi cudnymi willami, domami, gmachami, których dziś tu jeszcze spotykamy ruiny" (K-2 156). Wreszcie autor Kartek z podróży wspomina o trzęsieniu ziemi z r. 63 po Chr., gdy Pompeje zostały dotknięte „pierwszą straszliwą klęską, która była wybuchu przepowiednią [...]" (K-2 156). Tego wybuchu, który w kilkanaście lat później, w r. 79, unicestwił miasto, przysypując je - wylicza pisarz - na wysokość 22 stóp. Kraszewski skrupulatnie objaśnia, że przyczyną śmierci mieszkańców Pompejów nie była gwałtowna erupcja lawy, jak niegdyś sądzono, ale brak roztropności ze strony niektórych obywateli. Zasypywanie miasta nie było tak raptowne i szybkie. Oto bowiem, gdy na domy i gmachy w Pompejach zaczęły spadać rozgrzane popioły oraz kamienie, większa część ludności reagowała zbyt opieszale lub kryła się „do lochów i izb ustron- 
nadmiernych konkretyzacji o charakterze faktograficznym oraz empirycznym ${ }^{15}$, o tyle opis zostaje wręcz pozbawiony określania wzajemnych usytuowań, odległości, relacji między konkretnymi punktami w przestrzeni miejskiej. Rozbudzone oczekiwania czytelnika w zakresie topografii doznają tu ciężkiego zawodu. Jest on tym bardziej dotkliwy, że spodziewany porządek linearny, w jakim budowano i organizowano rzymskie centra, dawał w tej materii ogromne pole do popisu. Paradoksalnie: zawężona przestrzeń miasta staje się mniej konkretna, mniej uchwytna i realna ${ }^{16}$. Czytelnik Kartek $z$ podróży traci przede wszystkim kryteria empiryczne, dzięki którym mógłby dokonać identyfikacji terenu. Trudno określić, z której strony wkroczył Kraszewski do Pompejów - przypuszczalnie od północnego zachodu, Bramą Herkulańską, za którą rozciaga się ulica Grobów, a tuż obok niej ruiny, odkrytego jeszcze w XVIII wieku, wielkiego domu, zwanego także Willą Diomedesa, i współczesny pisarzowi Hotel Diomedesa, gdzie zatrzymywali się wtedy niemal wszyscy podróżni. W tym kierunku uda się Kraszewski opuszczając mury miasta, choć wyjeżdżając z Pompejów - co znamienne - już nie będzie, jak przy ich zwiedzaniu, unikał toponomastycznych gestów.

\section{Znikające punkty - ginąca przestrzeń}

Trzeba zwrócić uwagę na charakterystykę ulicy, którą wędruje Kraszewski tuż po przekroczeniu bramy miasta: jest wąska, $\mathrm{z}$ wysokimi chodnikami, $\mathrm{z}$ otaczającymi ją resztkami ścian zniszczonych domostw. Niemal jak refren powraca przy tym motyw ciasnoty i natłoku przestrzennego:

w czasie wielkiej ulewy, tak samo jak dziś w Neapolu, woda płynęła strumieniami po ciasnych uliczkach

nych, w których później zasypani, udusili się lub pomarli z głodu [...]. Spadające kamyki i popioły, ciemność nie dozwoliły im już wynijść na bezpieczniejsze miejsce" (K-2 157). Odnalezione ciała ludzkie stanowią dowód na poparcie tej tezy - dość pedantyczny opis ich umiejscowienia ma ją wydatnie wzmacniać. Próba odbudowy miasta, którego lokalizację przesunięto nieopodal, nie powiodła się - w $472 \mathrm{r}$. po Chr. los postapił z mieszkańcami podobnie jak 400 lat wcześniej. Już w XVIII w. zapomniano o Pompejach, a miejsce to zaczęło właściwie tętnić nowym, archeologicznym życiem. Kraszewski relacjonuje historię wykopalisk i podkreśla, że dotąd „to, co zostało odsłonięte, stanowi mniej więcej jedną trzecią część miasta samego, nie licząc przedmieścia Augustus Felix; ważniejsze jednak gmachy wszystkie niemal są oczyszczone" (K-2 159).

H. M ey er (Ksztattowanie przestrzeni $i$ symbolika przestrzenna $w$ sztuce narracyjnej. Przeł. Z. Ża bicki. „Pamiętnik Literacki” 1970, z. 3, s. 254) uważa, że skupianie opisowej energii na wspomnianych tu lokalizacjach jest jedną $z$ dystynktywnych cech epiki w stylu balzakowskim. Nie można przy tej okazji zapominać o tym, że „w planie Pompejów widzimy odchylenia od ściśle rygorystycznego planu geometrycznego. [...] nie notujemy w Pompejach wyraźnego skrzyżowania jakichś dwóch głównych osi, co miałoby przemawiać za tradycją etruską i rzymską. Obserwujemy tu natomiast zaakcentowanie kilku osi głównych (via Stabiana, via dell'Abbondanza, via di Nola), podobnie jak to bywało w greckich założeniach urbanistycznych" (A. W ą s o wi c z, Problem regularnego rozplanowania Pompejów. „Acta Universitatis Wratislaviensis. Antiquitas” t. 11〈1984〉, s. 101). Cechą charakterystyczną urbanistyki greckiej (ogólnego planu miast) jest w stosunku do założeń rzymskich mniejszy stopień rygoru geometrycznego. Grecki model zakłada bowiem dużą spontaniczność i przypadkowość założeń. Być może, Kraszewski wyczuwał tę subtelną różnicę, dając temu wyraz w swojej relacji. Chociaż jest to tylko perspektywa czysto teoretyczna, to - analizując sposób percepcji pisarza - nie można jej wykluczyć. 
[...]. Tam gdzie szły koleje wozów, zostawiono próżnie. Mowy być o tym nie może nawet, ażeby się tu dwa wozy minęły; miejsca starczy zaledwie na jeden. [K-2 163-164]

$Z$ jednej strony zatem mamy pustkę przestrzeni pompejańskich spotęgowaną jeszcze przez to, że pozbawione zostały walorów malarskich (freski bowiem - co skrupulatnie odnotowuje pisarz - przeniesiono z pietyzmem do muzeów); z drugiej zaś - wrażenie ciasnoty, skrępowania, braku swobody. Owa ambiwalencja i owo niezdecydowanie dotyczą nie tylko jednej ulicy, właściwie rozciagają się na całą miejska przestrzeń, co też budzi pewne zastanowienie deskryptora: „Ciasnota uliczek [...] wydaje się dziwną zrazu" (K-2 163). Tym większe, że opis nie zgadza się ze stanem faktycznym. Zwykłe, nieduże ulice, gdzie nie odbywał się większy ruch ani transport, mierzą od 3 do $5 \mathrm{~m}$ szerokości, jednak już słynna decumanus maximus, czyli ulica Obfitości ma około 8,5 m szerokości, a jej chodniki $4-4,30 \mathrm{~m}^{17}$. Co prawda, Kraszewski nie mógł jej widzieć w pełnej okazałości, ponieważ najważniejsze prace wykopaliskowe na tym odcinku podjęto dopiero w latach dwudziestych ubiegłego wieku, niemniej jakieś wyobrażenie na temat jej wymiarów musiał wynieść choćby z fragmentów już odsłoniętych. Natomiast zapewne znał niewiele węższą od wspomnianej głównej arterii ulicę Nolańską czy też cardo maximus, czyli ulicę Stabiańską. Czyżby pisarz świadomie mijał się z prawdą. A może nie zdawał sobie sprawy $z$ wagi i znaczenia, jakie dla Rzymian miały ulice? Nie odczytywał ich geometrycznego porządku i narzuconego przez ten porządek przestrzennego układu miasta - zgodnie $\mathrm{z}$ zasadą: ulica istniała przed miastem ${ }^{18}$

Brak tej zasady wydaje się bardzo znaczacy dla relacji. Zatarcie geometrii wskazuje bowiem sens i charakter kolejnych etapów wędrówki. Przede wszystkim są one pozbawione punktów na planie - nawet gdy padają nazwy i określenia wybranych miejsc, nie otrzymujemy informacji na temat ich usytuowania geograficznego. Wymienione i zestawione obok siebie trzy fora: Civile, Triangulare i Boarium, znajdują się w przeciwległych częściach Pompejów. Więcej miejsca przeznacza autor na opis tego pierwszego, zwłaszcza zaś kompleksu sakralnego, świątyń Jowisza i Mer-

17 Wymiary ulic w Pompejach podaję za Éti en ne'e m (op. cit., s. 247 n.). M. B e a rd w monografii Pompeje. Życie rzymskiego miasta (Przeł. N. Ra d o m s ki. Poznań 2010, s. 75-76) podkreśla zróżnicowanie pompejańskich arterii: „Niektóre z bocznych uliczek nie były nawet brukowane, ale pozostały ziemnymi traktami albo mało pociągającymi zaułkami wśród zwartej zabudowy; a na wcześniejszych etapach dziejów miasta znacznie więcej z nich musiało przypominać raczej błotniste lub pyliste ścieżki niż porządne, wykonane wedle wszelkich reguł sztuki drogi. Niektóre, zwłaszcza główne arterie przecinające miasto, były stosunkowo szerokie, w innych nie zmieściłby się jeden wóz. Przy czym wszystkie one były wąskie wedle naszych pojęć, rzadko ponadtrzymetrowej szerokości. [...] jedynie kilka dróg było tak szerokich, by dwa pojazdy mogły się wyminąć. A gdy budynki stały w całej okazałości, często z górnymi piętrami, nawet szersze ulice musiały wydawać się znacznie węższe i ciaśniejsze niż obecnie”.

18 Opis Kraszewskiego, uwypuklający nieporządek przestrzenny i dowolność, jeszcze mocnej przemawia do naszej wyobraźni, jeśli zestawimy go z zasadami rzymskiego planu urbanistycznego, opartego na absolutnej symetrii. Projekty urbanistyczne w starożytnym Rzymie nazywano „rzymskim planem siatkowym” i choć nie był on wynalazkiem Rzymian, ale Sumeryjczyków, to właśnie nad Tybrem doprowadzono go do mistrzostwa. Przy tym w opisie Kraszewskiego trzeba także uwzględniać fakt, że urbanistyczny porządek w przypadku Pompejów nie do końca realizował zasady „rzymskiego planu siatkowego". Zob. W ą s o w i c z, loc. cit. 
kurego oraz Wenery, a nadto omawia „pałac Eumachii ${ }^{19}$, której posagu odlew stoi tu na dawnej podstawie, chalcydyk poświęcony zgodzie i pobożności, choć zagadkowego przeznaczenia, uchował pamiątkę założycielki, kapłanki publicznej, która go wzniosła w imieniu swoim i syna" (K-2 166) ${ }^{20}$.

Informacje i opisy są dość zdawkowe, dotykają zaledwie jednego, dwu lub trzech szczegółów architektonicznych. Czasem deskryptor roztacza przed nami widok o znacznie szerszej, niemal wedutowej perspektywie. Nie pozwala sobie wszakże na dłuższy przystanek i delektowanie się widokiem ruin. Nie otrzymujemy też informacji na temat układu i usytuowania budowli na Forum - pisarz wyraźnie od tego stroni. Stąd pojawiają się tu najczęściej zdania: „Z drugiej strony świątynia Wenery [...]" (K-2 166) - z których trudno wywnioskować, czy chodzi o druga stronę placu rynkowego, czy też o drugą stronę budynku (w świątyni Jowisza oddawano cześć także Junonie i Minerwie i składano im ofiary). A może po prostu Kraszewski niewłaściwie identyfikuje - choć zgodnie $z$ ówczesnym stanem wiedzy - patrona świątyni, usytuowanej po zachodniej stronie Forum? Obecnie uznaje się, że była ona poświęcona Apollinowi.

Na północ od Forum, ściślej: dwie przecznice w górę - oczywiście, Kartki z podróży nie notuja położenia - znajduje się tzw. Dom Pansy czy, jak się obecnie przyjmuje: Gnejusza Allejusza Nigidiusza Majusa, członka jednej z bogatszych i bardziej zasłużonych rodzin ${ }^{21}$. Świetny to przykład - jak notuje Kraszewski - nie tylko pompejańskiej, lecz także rzymskiej domus. Dość skrupulatny opis prowadzony jest tak, aby wydobyć cechy typowe dla tego rodzaju obiektów, a nie właściwości przynależące temu konkretnemu domowi i wyróżniające go spośród innych. Nie inaczej wspomina o Willi Diomedesowej, usytuowanej poza granica murów miejskich, oraz o termach. W przypadku łaźni Kraszewski sumiennie przyznaje, że korzysta z książki Johannesa Adolfa Overbecka (wydanej 3 lata wcześniej w Lipsku), dokonujac przy tym stosownego wypisu ${ }^{22}$. Raz po raz relacja pisarza bywa wzbogacana lub konfrontowana $z$ literatura przedmiotu ${ }^{23}-\mathrm{w}$ takim samym stopniu

Obecnie przyjmuje się, że budynek ten poświęcony był boginiom Concordii Auguście i Pietas Auguście - pod którym to mianem kryli się Tyberiusz i Liwia. Pałac Eumachii zaś nazywany jest obecnie Gmachem Eumachii, która była kapłanką pompejańską. Zob. B e a r d, op. cit., s. 254-255 n. Był to cały kompleks architektoniczny, do którego należy zaliczyć przedsionek (chalcidicum), portyk (nie pojawia się w relacji pisarza), krużganek (crypta) oraz folusz (fullonica), będący miejscem przetwarzania i zarazem sprzedaży wełny. Niegdyś przyjmowano, iż posag kapłanki wznieśli właśnie folusznicy. Obecnie uznaje się, że Eumachia wystawiła budowlę, aby wspomóc w ten sposób karierę swego syna. Zob. ibidem, s. 255.

21 Zob. ibidem, s. 134.

22 J. A. Ove rb e ck, Pompeii. Leipzig 1855. Johannes Adolf Ove r b e c k (1826-1895) był znanym niemieckim archeologiem i historykiem sztuki, który prowadził prace wykopaliskowe na terenie Herkulanum i Pompei. Wykładał na Uniwersytecie w Lipsku, ale także pomagał w kierowaniu Instytutem Archeologii w Berlinie w latach 1874-1895. Interesowała go głównie kultura i sztuka starożytnej Grecji; z tej dziedziny ogłosił sporo istotnych prac naukowych, m.in. Geschichte der griechischen Plastik (t. 1-2. Leipzig 1857-1858).

23 Kraszewskiemu chyba nie było znane przełomowe dzieło dotyczące dziejów badań w Pompejach, 3-tomowe Pompeianarum antiquitatum historia (Neapoli 1860-1864), którego autorem był G. Fi orelli. Przygotował on też naukową i systemową metodę prowadzenia wykopalisk na tym terenie (przed nim prace były dość chaotyczne). W tamtym czasie istniała już ogromna liczba rozpraw 
korzystał Kraszewski $z$ własnych notatek, jak i z rozlicznych kompendiów, co sprawiło, że w Kartkach $z$ podróży zanotowanych jest w istocie kilka wojaży: zarówno te realne, jak i wirtualne, powtarzające wcześniejsze itinerarium już w przestrzeni notatek i książek, w zaciszu biblioteczno-gabinetowym ${ }^{24}$.

Uderza w relacji Kraszewskiego brak ruchu narratora-podróżnika, co sprawia, że z przestrzeni znikają linie dróg i punkty orientacyjne, a wędrówka zatraca swój spodziewany porządek i sens. Brak potrzeby poszukiwania czy choćby sugerowania istnienia centrum symbolicznego - miejsca stanowiącego arche miasta, mogącego organizować wymieniane wcześniej entropie - wskazywałby, że mamy do czynienia z flâneurem, który karmi się naocznością i w równym stopniu przyswaja sobie dostępną sobie wiedzę, by obie te sfery spożytkować później w swojej relacji ${ }^{25}$. Zapewne postawa ta nie była zupełnie obca Kraszewskiemu przemierzającemu ulice Pompejów, równocześnie jednak rozliczne miejskie eksploracje pisarza, co dowodnie pokazuja inne fragmenty Kartek z podróży, ale także pamiętnikowo-dziennikowe wspomnienia $z$ wędrówek krajowych czy wojażu odeskiego, niemal zawsze miały ściśle określony cel: najczęściej był on związany z odkrywaniem głębokiego znaczenia odwiedzanych miejsc, rozpoznawaniem ich historyczno-kulturowego i aktualnego oblicza.

W jakimś sensie Kraszewski przewartościowuje przestrzeń Pompejów, a jego wędrówka redukuje ideę przestrzeni usytuowanej do tego stopnia centralnie, że rzymskie pojęcie umbilicus, stanowiące podstawę lokacji miejskich opartą na topografii i symbolice geometrycznej, przestaje istniec ${ }^{26}$. Rozproszenie miejsc, ciasnota

naukowych poświęconych Pompejom i Herkulanum, jak choćby 4-tomowe Les Ruines de Pompéi (Paris 1812-1838) F. Mazois.

Istotnym źródłem wiedzy dla Kraszewskiego była także jego wizyta - opisana zresztą we wcześniejszych rozdziałach Kartek $z$ podróży - w neapolitańskim Museo Reale Borbonico (pod tą nazwą od r. 1816), które istniało jako rodzaj królewskiej galerii ze starożytnościami i malowidłami od 1750 roku. Znajdowały się tu liczne przedmioty pochodzące $z$ wykopalisk prowadzonych w Herkulanum, Pompejach, Stabii i Kumach. Później muzeum przemianowano na Museo Nazionale. Zob. W. Benjamin, Pasaże. Red. R. Tie demann. Przeł. I. Kania. Posł. Z. Ba uman. Kraków 2005, s. 461-501.

26 R. Se nn ett (Ciało i kamień. Człowiek i miasto w cywilizacji Zachodu. Przeł. M. Ko ni ko w s ka. Gdańsk 1996, s. 90) pisze: „Chcąc stworzyć miasto [...] Rzymianie najpierw wyznaczali punkt zwany umbilicus - środek, odpowiednik pępka u człowieka. Ów pępek miasta był dla projektantów podstawą wszelkich dalszych obliczeń i pomiarów. Umbilicus znajduje się również na podłodze Panteonu. Przy grze w szachy albo w warcaby środkowe pole ma ogromne znaczenie strategiczne i tak też jest w Panteonie: centralny kwadrat posadzki leży dokładnie pod okragłym "okiem" w kopule, pod okiem $z$ widokiem na niebo”. I dalej jeszcze autor dodaje: „Właśnie obserwując niebo, projektanci ustalali umbilicus miasta. Szlak słońca najwyraźniej dzielił sklepienie niebieskie na połowy; ruch gwiazd nocą kreślił drugą linię podziału, prostopadłą do tamtej dziennej, niebiosa więc składały się z czterech części. Żeby założyć miasto, szukało się na ziemi miejsca położonego dokładnie pod punktem, gdzie się stykały te ćwiartki, zupełnie jakby na ziemię rzutowało się mapę nieba. Znając już środek, urbaniści mogli wyznaczyć skraj miasta. Orano tam bruzdę zwaną pomerium - świętą granicę. Naruszyć pomerium, pisał Liwiusz, to jak okaleczyć ciało człowieka, zbytnio je rozciagając. Po określeniu środka i granic wytyczano dwie główne ulice, tak żeby się przecięły pod katem prostym w umbilicus. Nazywały się decumanus maximus i cardo maximus. Tym sposobem powstawały symetryczne ćwiartki; następnie każdą dzieliło się na cztery. Teraz miasto miało szesnaście sektorów. Dzielono je dalej, aż wyglądało niczym posadzka Panteonu". 
uliczna, wrażenia natłoku i zagubienia prowadzą nas wprost do skojarzeń związanych $\mathrm{z}$ błędnikiem i labiryntowymi zmaganiami wędrowca ${ }^{27}$.

Ta perspektywa nie do końca przekonuje. Narratorowi obce jest przede wszystkim poczucie niepewności i wrogości otaczającego go świata, więcej: narrator zachowuje się tak, jakby miejsca, które przemierza, były mu dobrze znane. To po pierwsze. I po drugie: trudno tu mówić, podobnie jak w wędrówkach usytuowanych labiryntowo, że mamy do czynienia $\mathrm{z}$ nadmiarem przestrzeni, z zagubieniem, brakiem pewności i natłokiem wrażeń zewnętrznych. Pamiętamy przecież, iż Kraszewski z pełnym rozmysłem dokonuje selekcji - opisuje tylko wybrane obiekty. Można także mówić o radykalnym ograniczaniu elementów świata przedstawionego ${ }^{28}$. W konsekwencji przestrzeń gdzieś ginie, ulega rozproszeniu, co prawdopodobnie ma związek $\mathrm{z}$ faktem, że Pompeje to miasto umarłych. Elementy tego świata podlegają typizacji, a nie indywidualizacji - oto bowiem opisy, nawet jeśli dotyczą określonych obiektów, prowadzone są w taki sposób, aby uwypuklić ich funkcje i wartości. Gdy czytamy na temat wspomnianego wcześniej Domu Pansy, otrzymujemy raczej wizję modelową rzymskiej domus, a nie konkretnego domu. $Z$ podobną sytuacją mamy do czynienia przy opisie łaźni, świątyń, forum, tzw. bazyliki czy amfiteatru. Stąd na początku rozdziału 15 pojawia się dość znamienna wątpliwość, wyrażona już ex post:

Wszystko to razem wzięte, niestety, da jakiekolwiek pojęcie o starożytnym świecie, ale o Pompei...? Nie wiem. [K-2 176]

Pompeje są dla Kraszewskiego głównie miastem, które pozbawione zostało swojej wewnętrznej siły życiowej - i to bynajmniej nie w wyniku tragicznego kataklizmu z 79 roku. Z przestrzeni miejskiej znikły jej naturalne atrybuty - znaki i świadectwa życia, artefakty kultury i sztuki. Wywożono je stąd przecież, gdy tylko, w XVIII wieku, na wielką skalę ruszyły wykopaliska: setki, jeśli nie tysiące przedmiotów i urządzeń związanych z życiem codziennym mieszkańców. Zasilały one muzea publiczne (przede wszystkim Museo Archeologico di Napoli), także kolekcje prywatne. Dlatego też - jak powiada pisarz:

Ją [tj. Pompeję] trzeba objąć okiem po obejrzeniu muzeów, po wyuczeniu się tego, co tu stało, co to dopełniało, co poufalej jeszcze zbliżało do form tego życia. [K-2 176]

Oderwanie przedmiotów życia codziennego od ich naturalnego kontekstu, od naturalnego otocza przerywa ważny ciag: wypełniają one bowiem przestrzeń niepowtarzalnością własną i odrębnością, ale także zawsze wchodzą w relacje ze swo-

Zob. np. M. Thalmann, Labirynt. Przeł. A. Są polińs ki. „Pamiętnik Literacki” 1978, z. 3. - P. Santarcangeli, Księga labiryntu. Przeł. I. Bukowski. Red. nauk. A. Krawczuk. Warszawa 1982. - M. Głowiński, Labirynt, przestrzeń obcości. W: Mity przebrane. Dionizos, Narcyz, Prometeusz, Marchołt, labirynt. Kraków 1990 (tu także obfita literatura przedmiotu). M. Eli a d e, Próba labiryntu. Rozmowy z Claude-Henri Rocquetem. Przeł. K. Śr o d a. Warszawa 1992.

28 G. Poulet (Metamorfozy czasu. Szkice krytyczne. Wybór J. Bł oń s ki, M. Gł owiń s ki. Przedm. J. Błoń s ki. Warszawa 1977, s. 508) uważa, że jedną z istotniejszych cech labiryntu miejskiego jest narzucający się nadmiar przestrzeni. Specyfika ruchu w labiryncie wiąże się z niejasnymi i pogmatwanymi kierunkami ruchu, któremu towarzyszą rozmaite komplikacje i przeszkody. 
imi właścicielami. Mają jakąś tajemniczą, „mediumiczną” moc, pośrednicząc między przestrzenią wnętrza architektonicznego a człowiekiem. Dlatego wnętrze pozbawione - nazwijmy to umownie - naturalnych atrybutów może być tylko typem przestrzeni, uogólniona zasadą jej organizacji, nie zaś indywidualnym, konkretnym obiektem, niepowtarzalnym i jedynym. Również jasno i wyraźnie widać, gdzie lokuje swoje oczekiwania Kraszewski jako podróżnik i znawca sztuki, także jako znawca i zwolennik archeologii - zapewne jak Cyprian Norwid: „archeologii żywej”. W skrócie należałoby powiedzieć tak: nie mury czy też ruiny, ale ludzie interesują Kraszewskiego. Swoisty to paradoks, zważywszy, że o Pompeje, a nie o współczesne aglomeracje, jak Rzym czy Paryż, tu chodzi.

\section{Archeologia wyobraźni}

Tak opisuje Kraszewski ciasnotę ulic w starożytnych Pompejach:

Ulica jest wąska, ma wysokie, podniesione chodniki z obu stron, resztki ścian od domów ją otaczają. Domki te o szczupłych sklepikach i izdebkach formują skupione niby małe kwartały insulae. Dachów, wznioślejszych kolumn, domów wyższych nie widać całkiem, ogólna fizjognomia przedstawia jakby ruiny po pogorzeli. Ton murów i barwa panująca czerwona. Wszystko to zrazu wygląda pusto, odarte, złupione, bo co tylko w domach znajdowano, aż do obrazów malowanych na ścianach, zabierano do muzeów. Powydzierano nawet posadzki. Trzeba się domyślać i stawić myślą widziane po muzeach sprzęty, malowania, rzeźby itp. Ciasnota uliczek, na których bruku znać jeszcze wyraźnie koleje i ślady kół od wozów, które parę tysięcy lat temu przesuwały się tędy - wydaje się dziwną zrazu. Niektóre z nich z chodnikami zajmują nie więcej czterech do pięciu łokci. Chodniki nie są jednostajne, przynajmniej co do materiału, każdy miał prawo, a może i obowiązek utrzymywania ich i wedle zamożności a smaku murował je i wykładał kamieniami, marmurem, a nawet mozaiką grubą. Ponieważ w czasie wielkiej ulewy, tak samo jak dziś w Neapolu, woda płynęła strumieniami po ciasnych uliczkach, gdzieniegdzie widać kamienie wyższe przez szerokość ulicy, dozwalające przechodzić ją nie błocąc się. Tam, gdzie szły koleje wozów, zostawiono próżnie. Mowy być o tym nie może nawet, ażeby się tu dwa wozy minęły; miejsca starczy zaledwie na jeden. Musiały więc wymijać się na placach i tam, gdzie się ulice krzyżowały. Dla odpływu wody i ścieków gdzieniegdzie widać otwory do kanałów podziemnych. U zejścia się ulic stoją studnie pięknego kształtu. [K-2 163-164]

Charakterystyczne, że autor nie rozwodzi się szczegółowo na temat wymiarów arterii, unika drobiazgowych opisów konstrukcji drogi, funkcji poszczególnych jej elementów. Miast tego dociera do nas obrazowa egzemplifikacja zasadniczej obserwacji. A przy tym pusta ulica - obiektywnie przecież pusta w momencie, gdy widział ją Kraszewski - powoli wypełnia się przedmiotami i ludźmi, zaczyna pęcznieć i huczeć od miejskiego gwaru. Tak dzieje się nieustannie w tej relacji. Uwadze o małej powierzchni sklepów zrazu towarzyszy rysujący się coraz wyraźniej widok kupujących:

Sklepiki były szczupłe, jak w ogóle wszystkie budowy, kupujący w większej liczbie wnijść nie mogli, ściskali się u wystawy na chodniku, w ulicy i tam kupowali, co im było potrzeba. Ponad drzwiami zasuwanymi sklepów, w miejscu napisów były żywe obrazy i godła rozmaitych handlów. Amfora wywieszona odznaczała sklepik z winem, żarna młynarza, koza mleczarnię. Niektóre z tych znaków są dziś niezrozumiałe. W izdebkach tych poznajdowano mnóstwo drobnych przedmiotów z brązu, z żelaza, z kamienia, które stanowią zbiór jedyny w swoim rodzaju. Życie wygodne i zbytek wymagały już wówczas mnóstwa wyrobów podobnych dzisiejszym, których się często ani spodziewano znaleźć w małym miasteczku owej epoki. Rękodzielników, artystów, przemysłowców wszelkiego rodzaju, jakich ślad tu pozostał, zliczyć niepodobna. 
Mamy tu kowalów, ślusarzy, ceglarzy, cyrulików, mydlarzy, przekupników wonności i balsamistów do namaszczania ciał umarłych; apteki, lekarzów (ciekawe narzędzia chirurgiczne), złotników którym dzisiejsi przynajmniej smakiem nie dorównują, malarzy, rzeźbiarzy; folusze, farbiarnie itd. Domyślaja się, że w sklepach wielu, których przeznaczenia odkryć nie umiano, sprzedawano różne zapasy żywności. U jednego z przekupniów oliwy sklep nader wytworny przybrany był pięknymi marmurowymi płytami, a w naczyniach niektórych stały oliwki, które się do dziś dnia zachowały. W termopolach sprzedawano różne napoje chłodzące i rozgrzewające: wino gotowane korzenne, słodzone, wodę zaprawną sokami itp. [K-2 164]

Gdy pisarz zahaczy o szynk Fortunata, nie będzie się skupiał na tym, co pozostało $z$ bryły i murów tego budynku, na wyglądzie jego ruin, ale wydobędzie taki szczegół, który unaoczni nam to miejsce w czasach, gdy tętniło ono życiem. Oto zatem mamy „murowany stół, na którym stały czasza i naczynia [...]”, i do dziś sa widoczne „plamy od nich lepkie, jak po dzisiejszych szynkach” (K-2 164). Jeśli nawet Kraszewski przenosi uwagę na ruiny pomieszczeń, to stara się rekonstruować w wyobraźni pierwotny ich wygląd i określać zawartość ich wyposażenia. Dobrym przykładem działania tej wyobraźni archeologicznej może być opis pompejańskich łaźni publicznych. Oto widok na caldarium:

Jest to sala długa, w której końcu jednym podwyższona studnia, z drugiego kwadratowa sadzawka. Łaźnią stanowi środek. Para napełniała ją buchając ze stropu i ścian przyozdobionych prostym rowkowaniem. Kwadratowa sadzawka pełną była wody ogrzanej; okładziny marmurowe i stopień do siadania ją otaczały, naczynie marmurowe podobne do studzienki (labrum) służyło do obmywania się po łaźni wodą zaledwie letnią, która wydawała się prawie chłodna. Odważniejsi rzucali się, wychodząc, wprost do zimnej. Na tym nie kończyła się jeszcze łaźnia, gdyż po niej, jak dziś na Wschodzie, łaziennik wyciagał członki, szorował skórę, wycierał, a na ostatek namaszczał ciało olejami wonnymi z mirrą, nardem, cynamonem, co musiało nieboszczyków Rzymian tak czynić nieznośnymi jak pewnego subiekta aptekarskiego, pamiętnego mi na wieki zapachem cynamonowym wąsów swoich! Rozmaitych maści używanych przez Rzymian, a przeznaczonych szczególniej do nacierania piersi, rąk, włosów, kolan, nóg, wyliczyć trudno. Wierzono w specyficzne ich działanie właśnie na te, a nie inne ciała części. Kosztowne to były pachnidła. [K-2 174-175]

Przede wszystkim narrator jednoznacznie kształtuje swoją wypowiedź na podstawie wiedzy naocznej, i to bezpośrednio danej, a zatem odczuwanej jako sytuacja w teraźniejszości. Pozwala sobie nawet na angażowanie naszego zmysłu powonienia, co silniej ukonkretnia realność i bezpośredniość wizji. Rzeczywisty wygląd miejsc, które oglądał Kraszewski, schodzi na odległy plan. Dlatego też w całej relacji uderza przesunięcie punktu ciężkości z obiektywnego istnienia przedmiotów, czyli niezależnego od relacjonującego, $\mathrm{ku}$ ich istnieniu czysto subiektywnemu, nieomal fikcjonalnemu, co w zestawieniu $\mathrm{z}$ charakterem przekazu - „kartkami z podróży” - musi budzić przynajmniej zastanowienie. Jeśli zaś porównamy opisy Pompejów z innymi opisami tej samej wędrówki, choćby z Wenecji, Florencji czy z Rzymu, wyjdzie na to, że interesujący nas przypadek jest wyjątkowy. Ale też prowokujący. Prowokujący do pytań zasadniczych. Kraszewskiego nie zajmuje aktualny stan miasta, a więc, by tak rzec: jego ruinalna substancja. Było nie było - wówczas dość ważny przedmiot rozlicznych dyskusji na łamach prasy, książek archeologicznych, także sporów akademickich. Nie interesuje autora Kartek z podróży też stan wykopalisk - choć nie omieszkał opisać pokrótce ich burzliwej i długiej historii. Obce mu są również wizje romantyczne, przepełnione aurą tajemniczości, nasycone teatralnymi gestami i apokaliptycznym obrazowaniem, 
zatrudnionymi w służbie historiozofii. Gdzie zatem lokuje się podróżnicza wrażliwość Kraszewskiego? Za czym podąża jego wyobraźnia artystyczna i dokąd prowadzi go instynkt deskryptora?

\section{Napis - przestrzeń wciąż żywa}

Są znakiem rozpoznawczym pompejańskich budowli, świadectwem i śladem dawnej ludzkiej obecności: wskazują dobitnie, że w kikutach domostw prywatnych oraz budynków publicznych tętniło niegdyś życie, że place wypełniały się ludzkim gwarem. Napisy - bo o nich tu, rzecz jasna, mowa - mają ogromna siłe wyrazu. Przyciagają uwagę każdego, kto przemieszcza się wśród ruin i zgliszcz miasta. Sprawiają, iż mury - zimne, pokruszone przez kataklizm i czas - w przedziwny sposób ożywają, ba: tętnią wręcz jakimś tajemniczym pulsem, zarazem nadając przestrzeni znamię niezwykłej aktywności. Wobec braku przedmiotów, które wypełniały pomieszczenia Pompejów, to napisy pobudzają wyobraźnię i stanowią o antropologicznym charakterze tego miejsca. Mur z napisem i mur bez napisu to dla Kraszewskiego dwie zupełnie odmienne przestrzenie, choć przecież materiałowo i substancjalnie nie zmienione. Autor poświęca sporo czasu i uwagi w swojej relacji właśnie napisom. Mają one różną tematykę i wartość, długość i przeznaczenie: niektóre są praktyczne, inne znów krotochwilne, jeszcze zaś inne mają charakter erotyczny, a nawet obsceniczny. Przy tym pisarz żywo i z zainteresowaniem je komentuje. Oto np. jeden z miłosnych wierszyków opatruje dość znamiennym objaśnieniem:

Pierwszy wiersz jest dość ładny (Zdrów bądź, ktokolwiek kochasz, giń, kto w miłość skąpy!), ostatni dowodzi, że rzymskie Marcje podejrzewane być mogły o miłość podłego kruszcu. [K-2 167]

Komentuje też fragmenty z Tibulla i Owidiusza, Wergiliusza i Propercjusza, wyróżniające się często tym, że są „popsute” 29 . W tym bogactwie przejawów życia i ludzkiej aktywności nie brak gier słownych i rebusów, także zagadek, ogłoszeń (np. o wynajęciu domu), przestróg, szyldów sklepowych, szyldów wyborczych, form bliskich graffiti - a zatem wprowadzających element malarski, plastyczny, często również łączący się ze słowem - no i, oczywiście, rachunków kupieckich, sporządzanych na goraco, pod wpływem transakcyjnej chwili; wreszcie utrwalone sa na ścianach - co dziwaczne $z$ naszego punktu widzenia - takie wydarzenia, jak narodziny osła. Gdzie indziej na setki lat uwieczniono z kolei fakt, że ktoś właśnie dostał kataru. Rozrzut tematyczny - jak widać - dość spory, a specyfika i funkcja tych napisów nie wyznaczają sobie szczególnych barier czy granic. Pomysłowość owych

Niesłuszną i jednostronną krytykę Kraszewskiego co do poprawności zapisów pompejańskich murali usprawiedliwia dość ubogi wówczas stan badań nad historią łaciny. Dziś wskazuje się, że w Pompejach oprócz łaciny posługiwano się także językiem oskijskim i greckim, co miało zapewne wpływ na jakość owych archeologicznych zapisów. Poza tym wiele do życzenia pozostawiał stan świadomości lingwistycznej mieszkańców miast usytuowanych $z$ dala od stolicy. Zob. H. Myśli w i e c, Latinitas „Bompeiiana”, czyli o pompejańskiej łacinie potocznej. „Acta Universitatis Wratislaviensis. Antiquitas" t. 11 (1984). 
skryptorów publicznych musiała zatem być ogromna. Murale - bardzo różnie zresztą wykonywane (sa wśród nich także mozaiki) - zmieniają charakter ocalałych większych lub mniejszych fragmentów: domów, budynków publicznych, większych lub mniejszych zespołów architektonicznych. Niesione przez nie treści sprawiają, że ocalałe części i elementy domów przestają być anonimowe i martwe. Odkrycie napisów w Pompejach miało dla Kraszewskiego kapitalne znaczenie: uobecnieni zostali bowiem anonimowi autorzy, a nawet więcej - przestawali oni być anonimowi. Napis stanowił rodzaj sygnatury, był jak imię osoby ją składającej, a co za tym idzie - paradoksalnie - wydobywał z martwej i naznaczonej piętnem kataklizmu przestrzeni ślad życia, i to w ogromnej liczbie jego przejawów, przydzielał aktywności ludzkiej niewielkie i dość błahe role, choć wobec tragedii wulkanicznej te gesty nabierały cech heroicznych. Kraszewski powiada: „Brzmia one [tj. napisy] jakby wczorajszy wykrzyknik, tkwi w nich niedogasła iskierka jakaś, ale wkoło popioły" (K-2 181). W obliczu zagłady każdy element zyskuje wielkie znaczenie. Błędy czy językowe niedociagnięcia, o których wspomina autor Kartek z podróży tak ochoczo, stają się w jego relacji żywym obrazem ludzkiej aktywności, przejawem autentyczności i aktualności tego, co minione. Tytułem przykładu sięgnijmy po nieco dłuższy cytat:

Następne wiersze, niepoprawnie spisane z obłamków Owidiusza i Tibulla w ścianach bazyliki, dały powód do różnych dopisków i dlatego je tu przywodziemy (nie poprawiając):

$$
\begin{aligned}
& \text { Si potest et non vis cur gaudia differs, } \\
& \text { Spemque foves et cras usque redire jubes? } \\
& \text { Ergo coge mori, quem sinete vivere cogis, } \\
& \text { Manus erit certe non cruciasse boni } \\
& \text { Quod spes eripuit spes certe reddet amanti. }
\end{aligned}
$$

„Jeżeli możesz (kochać), a nie chcesz, dlaczegóż szczęście odkładasz, nadzieją żywisz i zawsze jutro powracać każesz? Myśl, że ten umrze, któremu żyć każesz bez siebie. I dzięki ci będą, żeś nie męczyła na próżno.... i odebrana nadzieja nową nadzieją się spłaci”.

Ktoś przeczytawszy to, dopisał też z szyderską powagą (i ortografią fantastyczną): „Qui hoc leget nunc quam posteae aled legat et nunquam salvos quiits supra scribict”. „Ten, kto to czytał, niech więcej nic już nie czyta, a temu, co pisał, niech się nigdy dobrze nie dzieje" (?).

Trzeci, rozsądzając sprawę, potwierdził zdanie drugiego i doskrobał: „Vere dicis”. „Masz, asan, słuszność”. [K-2 167-168]

Na tym tle, ożywianym aktywną i zaangażowaną postawą narratora, w komentarzach autorskich pojawiają się także aktualizacje. Kraszewski na ogół gospodaruje nimi oszczędnie, ale gdy się już ukazuja w tekście, brzmią nader wyraźnie i donośnie, choć - pozornie - sa jedynie jakimś nawiasowym zjawiskiem. Tak przecież należałoby rozpatrywać skojarzenie łacińskiej maksymy „Marti omnia vota valent” z przypisywanymi Ottonowi von Bimarckowi (mylnie zreszta) słowami: „Gewalt geht vor Recht [Siła idzie przed prawem]", albo znów mimochodem rzucona uwagę: „z taką ortografią jak u nas Mickiewicz na szybach w gospodzie” (K-2 166), oceniająca poprawność pompejańskich ściennych „wypisów” z Horacego, Owidiusza czy Wergiliusza.

Kraszewski przybył do Pompejów nie po to, aby - jak robił to niedługo po nim Józef Kremer, skądinąd zasłużony i zacny - dokonać przewodnikowego inwentarza obiek- 
tów miejskich wydobytych w trakcie wykopalisk ${ }^{30}$. Na pewno nie to było celem tej podróży. W tym sensie dość znamienna wydaje się uwaga umieszczona na początku rozdziału 15 Kartek $z$ podróży:

Ją [tj. Pompeję] trzeba objać okiem po obejrzeniu muzeów, po wyuczeniu się tego, co tu stało, co to dopełniało, co poufalej jeszcze zbliżało do form tego życia.

Inwentarz archeologiczny schodzi tu na odległy plan, choć Kraszewski umiał być przecież wytrawnym archeologiem ${ }^{31}$. W trakcie wizyty w Pompejach pisarz dał jednak pierwszeństwo przede wszystkim wyobraźni - oczywiście, wyobraźni przygotowanej, wykształconej, ugruntowanej uprzednią lektura, jakże rozległą i wielowymiarową. Wyobraźnia pozwala wiedzę naoczną, bezpośredni kontakt z zabytkiem, podporządkować myśli i woli podróżnika-eksploratora tak, aby był w stanie wskrzesić świat już dawno nie istniejący - dawno umarły. Najczęściej przywoływane określenie Pompejów to „miasto umarłych”. Do takiej formuły odwołuje się także Kraszewski, choć jego relacja prowadzona jest wbrew niej, wbrew utartym i skonwencjonalizowanym już wówczas schematom. Pod jego piórem możemy w tej przestrzeni miejskiej zobaczyć tłumy przechodniów, wozy przeciskające się wzdłuż wąskich, bocznych uliczek, sklepikarzy i polityków, pisarzy i prostytutki, handlarzy i poetów, żołnierzy i gladiatorów, możnych i biednych, mędrców i głupców, starców i młodych, bo „życie, jak dziś jeszcze we Włoszech, upływało na ulicy i na targu” (K-2 176). Zaglądamy także do miejsc znacznie bardziej intymnych - domów patrycjuszy, świątyń i pałaców. W końcu też Kraszewski poprowadzi nas na słynną ulicę Grobów, czyli usytuowany tuż za Bramą Herkulańską cmentarz pompejański. Nekropolie znajdowano również w innych częściach pozamiejskich, np. za Bramą Nolańska odkryto groby 4 lata przed przyjazdem Kraszewskiego, ale znane były także podobne miejsca za bramami Stabijską i Sarnusowa. Wskazując na architektoniczne bogactwo sepulkralnych form, zdobienia i ocalałe malowidła, pisarz stara się przede wszystkim (paradoksalnie) wydobyć z nich pierwiastek życia. Nawet drobna wzmianka o triclinium, gdzie odbywały się uczty pogrzebowe, usytuowanym nieopodal niewielkiego placu, który „wedle wszelkiego prawdopodobieństwa służył do palenia ciał” (K-2 179), uwypukla dość nieoczekiwanie ten aspekt rzeczywistości. Cmentarz, będący niegdyś odrębną przestrzenią, teraz stał się niespodziewanie

Takie było założenie całej włoskiej podróży J. Krem e r a (Podróż do Włoch. T. 4: 〈Z Livorno do Neapolu; Neapol, Pompeja). Wyd. A. Zaw a dzki. Wilno 1861).

31 Zob. J. Kostrzewski, Dzieje polskich badań prehistorycznych. Poznań 1949, s. 49-52. S. Św i e r z e w s ki: Prace naukowe J. I. Kraszewskiego $w$ zakresie archeologii klasycznej. „Meander” 1954, nr 9/10; Studia czarnomorskie J. I. Kraszewskiego w Odessie. „Archeologia” R. 6 (1954); Józef Ignacy Kraszewski jako archeolog. W sto pięćdziesiata rocznicę urodzin. Jw., R. 12 (1961). J. Śli w a, Czarnomorska wyprawa Józefa Ignacego Kraszewskiego. „Alma Mater” (Kraków) 2003, nr 53. Ostatni $z$ wymienionych autorów powiada: „Jak stwierdził już przed laty profesor Józef Kostrzewski, zawdzięczamy Kraszewskiemu pierwszy szczegółowy zarys pradziejów Polski i słowiańszczyzny, zawarty w dziele Sztuka u Stowian, szczególnie w Polsce i Litwie przedchrześcijańskiej, opublikowanym w Wilnie w roku 1860. Dzięki zestawieniu wszystkich dotychczas znanych znalezisk i opracowaniu całej dostępnej literatury książka Kraszewskiego stała się niezbędna dla wszystkich zajmujących się czasami przedhistorycznymi Polski i krajów sąsiednich i przyczyniła się też znacznie do rozbudzenia zainteresowania znaleziskami pradziejowymi” (s. 20). 
częścią właściwego miasta, zmienionego po kataklizmie w wielki grobowiec, „z którego żaden głos nie wyjdzie, po którym milczenie zostało z tylu żywotów ludzkich, tylu prac, cierpień, zabiegów tylu istnień bez śladu i wieści, bez dziejów [...]" (K-2 181). Grób tysięcy osób i zarazem utrwalone na wieki w ziemi oraz w kamieniu świadectwo energii oraz aktywności twórczej mieszkańców Pompejów. Taki obraz wyłaniający się z relacji musi rodzić pytanie o wizję dziejów. Kraszewski jednoznacznie opowiada się po stronie tych, którzy poszukuja - jak powiadał Norwid - jej „części żywotnej”32, czyli pozwalają odsłonić rzeczywisty obraz człowieka przeszłości, zrozumieć go w sensie antropologicznym i socjologicznym. Ta zdolność hermeneutyczna, którą bez wątpienia Kraszewski dzielił z twórcą Quidama, stanowi reakcję na poznawcza metodologię historyczną - silnie zaznaczająca swe istnienie właśnie od połowy XIX wieku - zawężająca epistemologiczne pole obserwacji do suchego, niemal buchalterskiego inwentarza wydobytych na swiatło dzienne artefaktów.

\author{
Abstract \\ PIOTR CHLEBOWSKI John Paul II Catholic University of Lublin \\ TOWN OF DEATH AN EPISODE FROM KRASZEWSKI'S ITALIAN CAMPAIGN
}

The article refers to a brief episode connected with Józef Ignacy Kraszewski's trip to Italy contained in his Kartki z podróży. 1858-1864 (Notes from Travels. 1858-1864), namely to Pompeii. Pompeii was a place of numerous romantic travels which explored the faces of the fall of the civilisation and passing of human achievements. Kraszewski did not make it a secret that it was Pompeii, alongside to monuments of the first centuries of Christianity, that became the central point on the trace of his grand tour. Significant here is the fact that for Kraszewski this type of epistemological behaviour, marked by voracity, makes room for a gesture of choice and a consciously deep reflection which, paradoxically, in a great cemetery seeks for tracks of life and old splendour as well as active creation. T. 3. 